\title{
Laboratory Investigations in Support of Carbon Dioxide-Limestone Sequestration in the Ocean
}

\author{
Semi-Annual Technical Progress Report \\ for the period \\ $7 / 9 / 2003-1 / 8 / 2004$
}

\author{
Dan Golomb, Eugene Barry, David Ryan, Carl Lawton \\ Co-Principal Investigators \\ Peter Swett and John Hannon \\ Research Assistants \\ Submitted January 2004 \\ Revised March 2004 \\ submitted to \\ US Department of Energy \\ National Energy Technology Laboratory \\ Award DE-FC26-02NT41441 \\ UML Project ST-105691 \\ University of Massachusetts Lowell, Lowell, MA 01854
}




\section{DISCLAIMER}

This report was prepared as an account of work sponsored by an agency of the United States Government. Neither the United States Government nor any agency thereof, nor any of their employees, makes any warranty, express or implied, or assumes any legal liability or responsibility for the accuracy, completeness, or usefulness of any information, apparatus, product, or process disclosed, or represents that its use would not infringe privately owned rights. Reference herein to any specific commercial product, process, or service by trade name, trademark, manufacturer, or otherwise does not necessarily constitute or imply its endorsement, recommendation, or favoring the United States Government or any agency thereof. The views and opinions of authors expressed herein do not necessarily state or reflect those of the United States government or any agency thereof. 


\title{
Laboratory Investigations in Support of Carbon Dioxide-Limestone Sequestration in the Ocean
}

\begin{abstract}
In the first half of the second contractual year the High Pressure Flow Reactor (HPFR) was fully designed. Most components have been ordered, and assembly of the flow reactor has been started. Also, the High Pressure Batch Reactor (HPBR) was redesigned for more efficient operation and observation of the emulsion of liquid or supercritical $\mathrm{CO}_{2}$ dispersed in water stabilized by pulverized limestone and other particles.

In this period we firmly established that when about equal volumes of liquid $\mathrm{CO}_{2}$ and a slurry of pulverized limestone $\left(\mathrm{CaCO}_{3}\right)$ in de-ionized or artificial seawater $(3.5 \% \mathrm{NaCl}$ solution in de-ionized water) are thoroughly mixed, a macro-emulsion ensues consisting of liquid $\mathrm{CO}_{2}$ droplets coated with a sheath of $\mathrm{CaCO}_{3}$ particles dispersed in water. We call the coated $\mathrm{CO}_{2}$ droplets globules, and the macro-emulsion a globulsion. Depending on the degree of mixing (rotational speed of the magnetic stir bar) and the size of the $\mathrm{CaCO}_{3}$ particles, the globules float on top of the water column, are suspended in it, or sink to the bottom of the water column. With $\mathrm{CO}_{2}$ droplet diameter in the $100-200 \mu \mathrm{m}$ range, and $\mathrm{CaCO}_{3}$ particles in the 6 - $20 \mu \mathrm{m}$ range, most of the globules sink to the bottom. The formation of sinking globules is desirable for ocean sequestration of $\mathrm{CO}_{2}$. The properties and stability of the globules will be further investigated in the HPFR in the second contractual year.

It has also been demonstrated that flyash can be substituted for pulverized limestone to obtain a stable globulsion of $\mathrm{CO}_{2}$-in-water.
\end{abstract}




\section{TABLE OF CONTENTS}

EXPERIMENTAL

(a) High-Pressure Flow Reactor

(b) New High-Pressure Batch-Type Reactor

RESULTS AND DISCUSSION

Flyash Experiments

PLANS FOR THE NEXT PERIOD

CONCLUSION

PUBLICATIONS

GRAPHICS page

5

5

5

6

6

7

7

8 


\section{EXPERIMENTAL}

\section{(a) High Pressure Flow Reactor}

In the reporting period, the design of the High Pressure Flow Reactor (HPFR) was completed, and components thereof are already assembled. The schematic of the HPFR is presented in Figure 1 at the end of the report. The HPFR mixes a stream of liquid carbon dioxide with a slurry of pulverized limestone $\left(\mathrm{CaCO}_{3}\right)$ in water or seawater at pressures up to 2,500 psi.

The heart of the HPFR is a Kenics-type static mixer, which is depicted in greater detail in Figure 2. This is a tubular mixer 11 inch long with $1 / 4$ inch OD, with a series of 27 alternating helical baffles inside the mixer. Two fluids are forced into the mixer, one is liquid or supercritical $\mathrm{CO}_{2}$, the other is a slurry of pulverized limestone $\left(\mathrm{CaCO}_{3}\right)$. The high velocity in the narrow tube and the shearing and streamline cleaving action of the helical baffles efficiently mix the immiscible liquids, so that at the end of the tube a homogenized emulsion will ensue. The emulsion consists of liquid or supercritical $\mathrm{CO}_{2}$ droplets coated with a sheath of $\mathrm{CaCO}_{3}$ particles dispersed in water. We call this emulsion a globulsion. The globulsion will flow into the observation cell equipped with windows. The size distribution of the globules will be measured with a fast-frame video camera using the window dimensions as a scale reference. Furthermore, the fast-frame video camera will allow the measurement of the settling velocity of the globules. Using Stokes' Law, the measured globule diameter, and the viscosity of the medium (pure or saline water), the specific gravity of the falling globules can be measured.

Experiments presented by Tajima et al. at the 2nd Annual Conference on Carbon Sequestration demonstrated that monodisperse droplets of $\mathrm{CO}_{2}$-in-water can be obtained in this type of mixer. Our aim is to obtain uniform globules of liquid or supercritical $\mathrm{CO}_{2}$ coated with a sheath of pulverized $\mathrm{CaCO}_{3}$ that are heavier than seawater. From our batchtype experiments we established that if the size of the $\mathrm{CO}_{2}$ droplets is in the $100-200$ $\mu \mathrm{m}$ range, and the $\mathrm{CaCO}_{3}$ particle size is in the $6-20 \mu \mathrm{m}$ range, globules are formed with a specific gravity that is greater than that of seawater. Hence, if released in the deep ocean, such globules would sink toward the ocean bottom.

We expect the HPFR to be operational by the end of April 2004.

\section{(b) New High Pressure Batch Reactor}

In the reporting period a new and improved High Pressure Batch Reactor (HPBR) was constructed. The modified design of the HPBR is shown in Figure 3. Several limitations of the original batch reactor were addressed. As before, the cell comprises the intersection of two cylinders. However, some of the dead volume of the cylinders has been reduced in order to avoid stagnation of the globules outside of the field of view of the windows. Also, a curved bottom of the reactor will allow for higher rotational speeds of the stir bar and better mixing. More ports have been added for the insertion of a high pressure $\mathrm{pH}$ electrode assembly and other probes. The window material is tempered borosilicate glass (Pyrex), which permits operation up to $5000 \mathrm{psi}$ (34.5 MPa) and temperature up to $50^{\circ} \mathrm{C}$. A convective air bath allows more precise cell temperature regulation. 


\section{RESULTS AND DISCUSSION}

\section{Flyash Experiments}

In the new High-Pressure Batch Reactor we conducted further experiments with the aim of determining whether other pulverized materials than limestone can produce a stable globulsion. So far, we experimented with flyash. A sample of flyash was obtained from the Salem Harbor Station, Massachusetts, operated by the Pacific Gas and Electric Company. This is a 750 MW power plant with three pulverized coal-fired boilers, and one oil-fired boiler. The flyash sample was obtained from one of the coal-fired boilers. The flyash was collected by an Electrostatic Precipitator (ESP). The coal is a low-sulfur type of Venezuelan origin. The exact composition has not been established, but reputedly it has a fairly high Loss-on-Ignition (LOI) in the 12 - 18\% range. Indeed, the color of the flyash is grey-black, indicating a high carbon content. The consistency of the flyash is that of talcum powder.

We mixed $18 \mathrm{~mL}$ liquid $\mathrm{CO}_{2}, 10 \mathrm{~g}$ flyash, and $3 \mathrm{~g} \mathrm{NaCl}$ dispersed in $95 \mathrm{~mL}$ water at $15^{\circ} \mathrm{C}, 20 \mathrm{MPa}$, using the cylindrical magnetic mixing bar with a cross-shape on top of the cylinder. Rotational speed was $1500 \mathrm{rpm}$. Stable globules were formed, some of them heavier than water, hence they sank to the bottom of the view cell (Figure 4). This experiment demonstrates that flyash can produce a stable globulsion of $\mathrm{CO}_{2}$ droplets coated with flyash dispersed in water. Further experiments are planned using various types of flyash with known composition and size distribution. Flyash samples will be purchased from the National Institute of Standards and Technology (NIST) Standard Reference Material (SRM) program.

\section{PLANS FOR THE NEXT PERIOD}

In the next period we expect the High Pressure Flow Reactor (HPFR) to be fully operational. We shall commence establishing the operating conditions for the HPFR such that the $\mathrm{CaCO}_{3}$ coated $\mathrm{CO}_{2}$ globules sink to the bottom of the observation cell. The variables include relative flow rates of the two fluids $\left(\mathrm{CO}_{2}\right.$ and $\mathrm{CaCO}_{3}$ slurry), temperature, phase of $\mathrm{CO}_{2}$ (sub- or super-critical), injection pressure into Kenics mixer, and particle size of $\mathrm{CaCO}_{3}$. Refinement of the variables and measurement of the settling velocity of the globules will continue.

Also, in the next period we expect the new High Pressure Batch Reactor (HPBR) will be utilized to form particle stabilized globulsions of sub- and super-critical $\mathrm{CO}_{2}$ using the following particles: flyash, silica $\left(\mathrm{SiO}_{2}\right.$ in the form of pure sand), alumina $\left(\mathrm{Al}_{2} \mathrm{O}_{3}\right)$, iron filings, olivine, serpentine and carbon black. A wide range of particle sizes will be covered. 


\section{CONCLUSION}

In the first 18 months of the contractual period it has been amply demonstrated that a stable emulsion can be formed when liquid or supercritical carbon dioxide is mixed with a slurry of pulverized limestone $\left(\mathrm{CaCO}_{3}\right)$ in water. The emulsion consists of droplets of liquid or supercritical $\mathrm{CO}_{2}$ coated with a sheath of $\mathrm{CaCO}_{3}$ particles dispersed in water. We call the coated droplets globules, and the resulting macro-emulsion a globulsion. Depending on the globule diameter and the $\mathrm{CaCO}_{3}$ sheath thickness, the globules sink to the bottom of the water column, are neutrally buoyant, or float on top of the water. The

presence of particles reduces the interfacial tension by decreasing the interfacial area, and hinders coalescence of the $\mathrm{CO}_{2}$ droplets. Both a slurry of $\mathrm{CaCO}_{3}$ in de-ionized water and in artificial seawater (3.5\% $\mathrm{NaCl}$ solution in de-ionized water) forms the globulsion. The $\mathrm{CaCO}_{3}$ stabilized globulsion could be used for ocean sequestration of $\mathrm{CO}_{2}$. The globulsion, being denser than seawater would sink to greater depth from the injection point, and the $\mathrm{CaCO}_{3}$-coated $\mathrm{CO}_{2}$ droplets would not acidify the seawater, thereby not harming aquatic organisms.

We also demonstrated that flyash particles can be used instead of limestone particles to form a stable globulsion of $\mathrm{CO}_{2}$ in water.

\section{PUBLICATIONS}

1. We submitted to Environmental Sciences and Technology a manuscript entitled "Limestone Particle Stabilized Macro-Emulsion of Liquid and Supercritical Carbon Dioxide in Water for Ocean Sequestration”

The manuscript is presently undergoing peer review. Following is the Abstract.

When liquid or supercritical $\mathrm{CO}_{2}$ is mixed with an aqueous slurry of finely pulverized (1 $-20 \mu \mathrm{m})$ limestone $\left(\mathrm{CaCO}_{3}\right)$ in a high-pressure reactor, a macro-emulsion is formed consisting of droplets of $\mathrm{CO}_{2}$ coated with a sheath of $\mathrm{CaCO}_{3}$ particles dispersed in water. We call the coated droplets globules, and the resulting macro-emulsion a globulsion. Depending on the globule diameter and the $\mathrm{CaCO}_{3}$ sheath thickness, the globules sink to the bottom of the water column, are neutrally buoyant, or float on top of the water. The

presence of particles reduces the interfacial tension by decreasing the interfacial area, and hinders coalescence of the $\mathrm{CO}_{2}$ droplets. Apparently, a larger fraction of the surface of the hydrophilic $\mathrm{CaCO}_{3}$ particles resides in water than in carbon dioxide, resulting in an oil-in-water $(\mathrm{O} / \mathrm{W})$ ) type emulsion. We describe the expected behavior of a globulsion plume released at depth for ocean sequestration of $\mathrm{CO}_{2}$ in order to ameliorate global warming.

2. We submitted to the 7th International Conference on Greenhouse Gas Control Technologies (GHGT-7), to be held 5-9 Sep 2004 in Vancouver, BC, Canada the following Abstract. The Abstract has been accepted for poster presentation at the Conference.

Liquid Carbon Dioxide/Pulverized Limestone Emulsion Delivery System for Deep Ocean Storage 
We demonstrated previously (1) that when liquid or supercritical $\mathrm{CO}_{2}$ is mixed with a slurry of pure or saline water containing finely pulverized $(1-20 \mu \mathrm{m})$ limestone $\left(\mathrm{CaCO}_{3}\right)$, a macro-emulsion is formed consisting of $\mathrm{CO}_{2}$ droplets coated with a sheath of $\mathrm{CaCO}_{3}$ particles dispersed in water. The sheathed droplets are called globules, and the dispersion of globules in water is called a globulsion. Depending on the globule diameter and the $\mathrm{CaCO}_{3}$ sheath thickness, the globules sink to the bottom of the water column, are neutrally buoyant, or float on top of the water column. Using a Kenics-type static mixer and pulverized limestone with particle size in the $5-10 \mu \mathrm{m}$ range, monodisperse globules of about $200 \mu \mathrm{m}$ diameter can be produced. Assuming a monolayer of pulverized limestone around the globules, the specific gravity of each globule is greater than that of seawater. For complete encapsulation of liquid $\mathrm{CO}_{2}$ about $0.6 \mathrm{t}$ of limestone is needed per ton of $\mathrm{CO}_{2}$. The globulsion has a slightly alkaline $\mathrm{pH}$.

A practical delivery system for the underwater creation of the globulsion is described. Liquid $\mathrm{CO}_{2}$ is piped to about $500 \mathrm{~m}$ depth along the continental shelf or precipice. This depth is below the flash point of liquid $\mathrm{CO}_{2}$ into vapor. A dense slurry of pulverized limestone in seawater is separately piped along the $\mathrm{CO}_{2}$ pipe. A Kenics-type static mixer is mounted on the bottom slope. Three fluids are entering the static mixer: (a) liquid $\mathrm{CO}_{2}$, (b) the dense slurry of pulverized limestone, and (c) ambient seawater pumped into the mixer by a turbine. The quantities of each fluid are metered so that complete encapsulation of $\mathrm{CO}_{2}$ is obtained, and the resulting globulsion is denser than ambient seawater. The globulsion plume will sink several hundred meters along the slope while entraining ambient seawater until the plume reaches neutral buoyancy. Then the globules will roll- out from the plume further along the slope to greater depth. In the open ocean, liquid $\mathrm{CO}_{2}$ and pulverized limestone are barged to an anchored platform. A static mixer and a seawater turbine are attached to the anchors at a depth of about $500 \mathrm{~m}$. The three fluids are mixed as above in the static mixer. The dense globulsion plume will sink several hundred meters while entraining seawater until a neutral buoyancy is reached. Then the $\mathrm{CaCO}_{3}$ encapsulated $\mathrm{CO}_{2}$ globules will rain-out from the plume toward the ocean bottom. With this method of discharging $\mathrm{CO}_{2}$, the ocean will not be acidified.

(1) Golomb, D. Carbon Dioxide/Limestone/Water Emulsion for Ocean and Geologic Sequestration of $\mathrm{CO}_{2}$, GHGT-6, J. Gale and Y. Kaya (Eds.), Elsevier Science Ltd., Vol. I, pp. 683-688, 2003.

\section{GRAPHICS}

Figure 1: High Pressure Flow Reactor

Figure 2: Kenics-type Static Mixer Detail

Figure 3: Modified High Pressure Batch Reactor

Figure 4: Flyash Globulsion in Simulated Seawater 


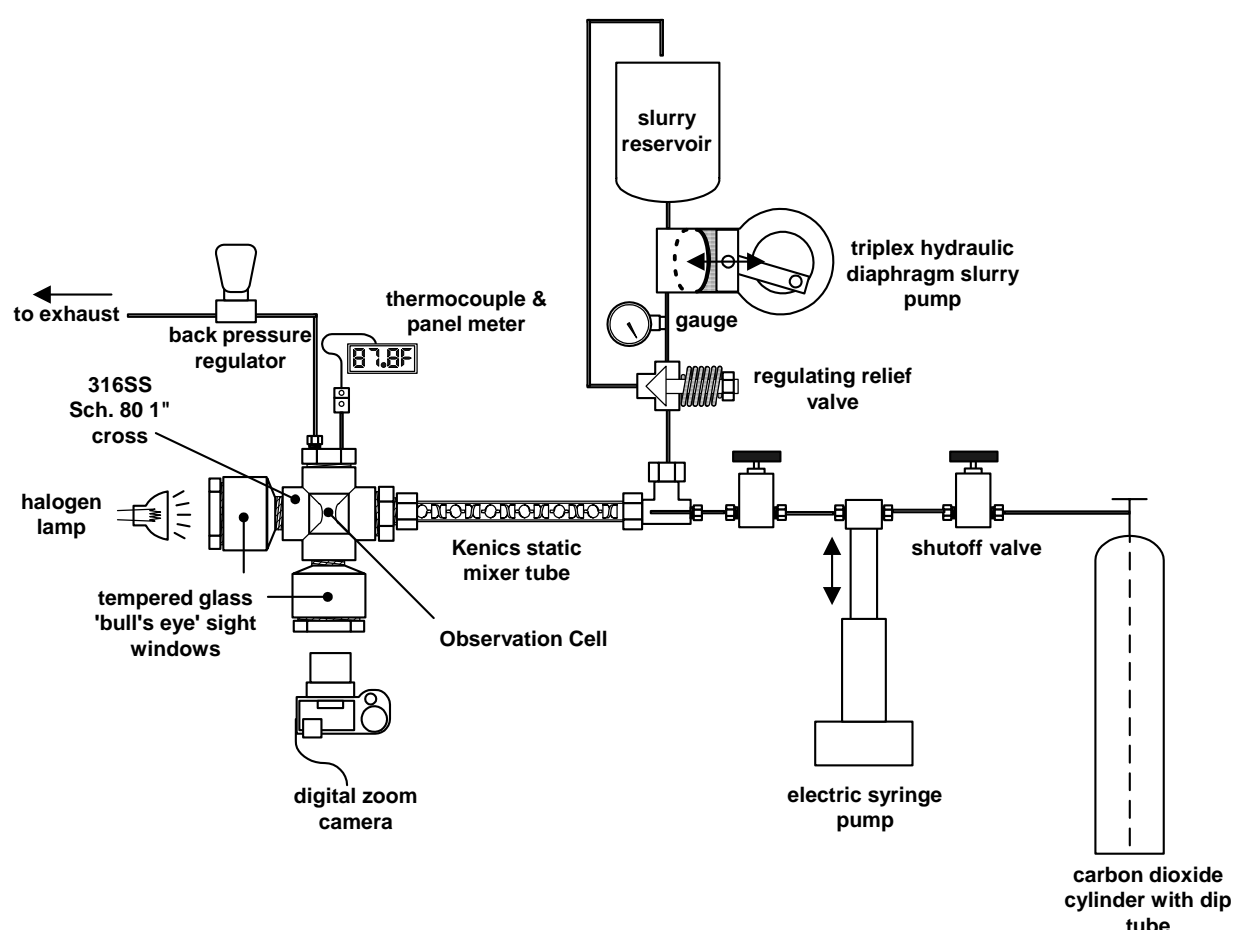

Figure 1: High Pressure Flow Reactor

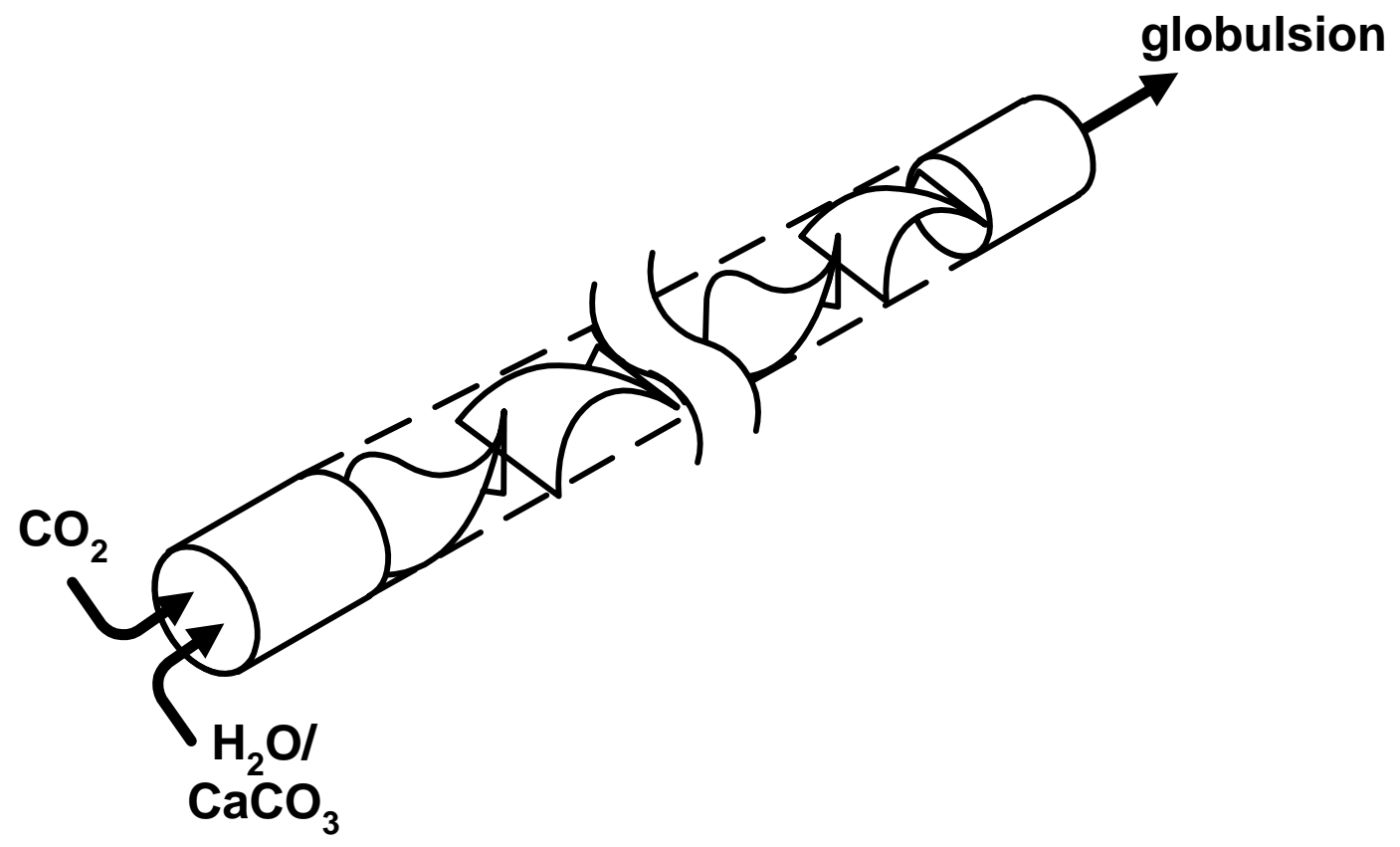

Figure 2: Kenics-type Static Mixer Detail 


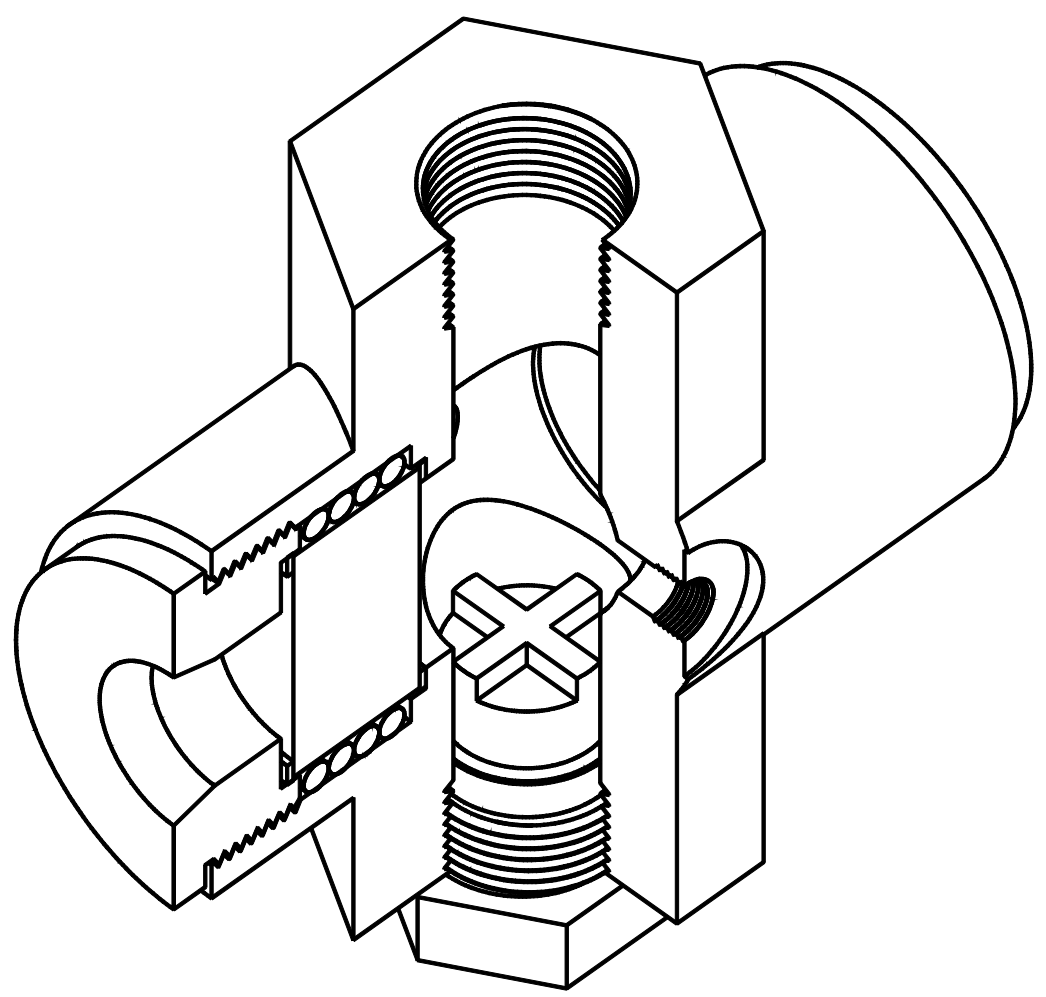

Figure 3: High Pressure Batch Reactor

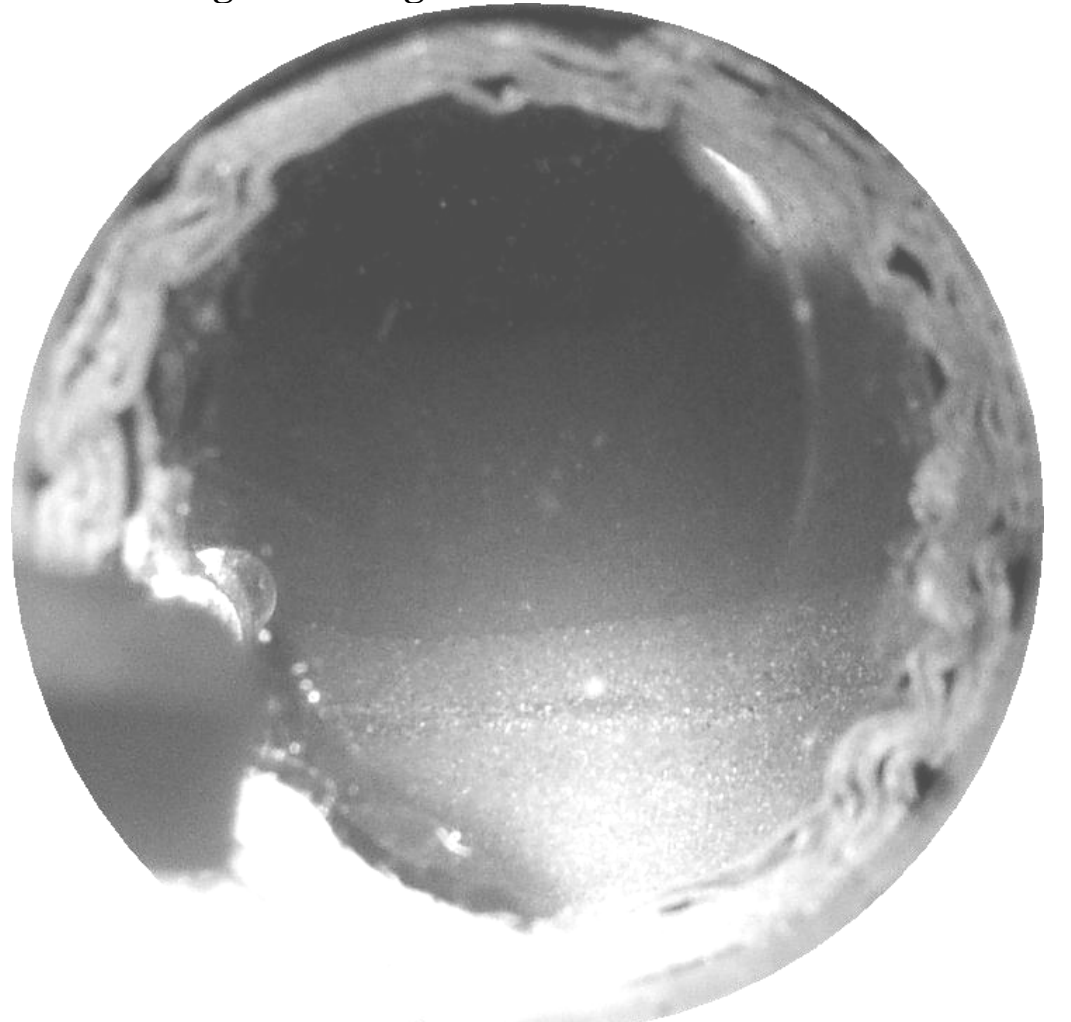

Figure 4: Flyash Globulsion in Simulated Seawater 